\title{
The Potential of Small-Scale Agro-Industry as a Sustainable Livelihood Strategy in a Caribbean Archipelago Province of Colombia
}

\author{
Magda M. Masquita Mckeller (Corresponding author) \\ Department of Environmental Studies, College of Environmental Science and Forestry-1 Forestry Drive \\ State University of New York, 1 Forestry Drive, Syracuse NY 13210, USA \\ Tel: 578-513-3856 E-mail: magdammc@fulbrightmail.org \\ Richard C. Smardon \\ Department of Environmental Studies, College of Environmental Science and Forestry - 1 Forestry Drive \\ State University of New York, Syracuse NY 13210, USA \\ E-mail: rsmardon@esf.edu
}

Received: January 5, 2012

Accepted: January 21, $2012 \quad$ Published: March 1, 2012

doi:10.5539/jsd.v5n3p16

URL: http://dx.doi.org/10.5539/jsd.v5n3p16

\begin{abstract}
San Andrés, Providence, and Santa Catalina were declared a biosphere reserve in the year 2000; as an effort to protect biodiversity and to promote sustainable development. This declaration entails the development of sustainable economic activities that ensure environmental conservation and the community's wellbeing. Surveys and interviews were used to determine the characteristics of small-scale agro-industry and the perceptions about its sustainability as a livelihood strategy for the Archipelago. The study concludes that agro-industry, as it is currently practiced in the Archipelago, is not sustainable in the long-term. However, it has potential to become a sustainable livelihood strategy. This study calls for efforts to strengthen agriculture and protect local agro-industry production, aiming for a steady supply of raw materials for agro-industry and an assurance of local markets for the products. Further studies on adapting and coping strategies and the contributions that modern technology might offer to artisanal agro-industry are suggested.
\end{abstract}

Keywords: Small-scale agro-industry, Rural livelihood, Sustainable livelihood, Seaflower biosphere reserve, Colombia.

\section{Introduction}

Promoting and supporting family agro-industry livelihood systems could provide alternative livelihood opportunities for rural people and enhance the possibility for local development. The generation of value-added products through agro-industry brings employment and economic benefits for rural households, mostly for families whose livelihoods depend on seasonal income-generating activities. The sustainable livelihoods approach is a framework for developing effective strategies for sustainable development and poverty alleviation. Although poor people usually choose the activities to engage in for their livelihood, there are limitations and challenges that need to be overcome in order to ensure sustainability. Designing policies that improve the capability of families engaged in processing agricultural products to provide high quality products in a sustainable way could result in better and higher incomes for those families.

The focus of this paper is on the livelihood of rural people engaged in agro-industry in San Andrés, Old Providence, and Santa Catalina Islands, an archipelago belonging to Colombia and located in the southwestern Caribbean. This is a first approach to providing a general description of the assets, capabilities, and activities of rural households engaged in agro-industry, and the institutions and organizations that have an impact on them. By describing key characteristics of small-scale agro-industrial systems in the Archipelago and analyzing the importance of agro-industry for rural households' livelihood, this paper intends to provide a clearer understanding of the challenges and opportunities related to sustainable livelihood in the islands and the need for support to be provided to small-scale agro-industry. 


\subsection{Sustainable Livelihood}

The concept of livelihood has been widely used as a theoretical basis for research on topics like livelihood and sustainability (Tao \& Wall, 2009), livelihood diversification and gender (Simtowe, 2010), community development and sustainable livelihood (Brocklesby \& Fisher, 2003), livelihood security (Bhandari \& Grant, 2007), the value and challenges of livelihood studies (de Haan \& Zoomers, 2005), and organizational approaches to the sustainable livelihood framework (Hussein, 2002). Chambers and Conway (1992) described livelihood as the set of capabilities, assets, and activities which people use to make their living.

Drawing from the work of a wide range of authors whose work centers on sustainable development and livelihood strategies, the present study finds that a sustainable livelihood is characterized by

- $\quad$ its ability to cope with, recover from, and adapt to stresses and shocks;

- $\quad$ its power to maintain or enhance its capabilities and assets both now and in the future;

- $\quad$ its capacity to provide and enhance sustainable livelihood opportunities for the next generation;

- $\quad$ its potential to contribute net benefits to other livelihoods at the local and global levels and in the short and long term; and

- the ability to do all the above without overexploiting the natural resource base.

Chambers and Conway (1992) classify sustainability as environmental and social. Environmental sustainability refers to the impact on the local natural resource base (e.g., deforestation, declining water tables, or improved productivity of soil) and the impact on the long-term environmental sustainability of other livelihoods at a global scale (e.g., pollution, greenhouse gases, or the irreversible use of non-renewable resources). Social sustainability involves the capacity to resist outside pressures, which the researchers categorize as stresses and shocks.

External factors such as institutions (Brocklesby \& Fisher, 2003; de Haan \& Zoomers, 2005; Ellis \& Mdoe, 2003; Scoones, 1998; Tao \& Wall, 2009) and organizations (de Haan \& Zoomers, 2005) also play crucial roles in constructing a sustainable livelihood by allowing the necessary conditions for people to effectively combine and allocate resources, both tangible (assets) and intangible (capabilities and activities).

The sustainable livelihoods approach is a paradigm that brings together the notions of wellbeing, security, and capability through in-depth multidimensional analysis of existing poverty-related issues, development issues, and natural resources sustainability. Moreover, this approach indicates that the development of poverty reduction programs should begin with an assessment of poor communities' current strengths, resources, activities, knowledge, and skills, in contrast to previous approaches based on income, consumption, and employment methodologies (Bhandari \& Grant, 2007; Brocklesby \& Fisher, 2003; Kaushal \& Kala, 2004; Krantz, 2001; Tao $\&$ Wall, 2009). Hence, the sustainable livelihoods approach is based on relationships between the assets people possess and the institutional and organizational contexts within which their livelihood strategies develop. Understanding these relationships is core to identifying ways to make livelihoods more productive and sustainable (Ellis \& Bahiigwa, 2003; Hussein, 2002; Kay, 2006; Tao \& Wall, 2009).

\subsection{Agro-Industry}

According to the UN Commission on Sustainable Development [UNCSD] (2008), agro-industry is "the processing, preservation and preparation of agricultural production for intermediate and final consumption". Gibb and Smilga-Palardy (2006) argue that small-scale agro-industry "has the potential to improve small farmers' livelihood quality by providing them with an additional source of income" (p. 9); in this way, small-scale agro-industry could be established within a sustainable rural development strategy.

In the Latin American context, agro-industry is the most important industrial branch, contributing close to a third of all manufactured products. In the largest countries (Argentina, Brazil, and Mexico), it contributes less than 20 percent of manufactured products. In Colombia, Chile, and Venezuela, it contributes 30 percent, and in other countries it contributes more than one third (Boucher \& Riveros, 2000).

As specified by UNCSD (2008), agriculture and agro-industry need to be recognized as sectors that have positive impacts on development and economic growth. Furthermore, policies should consider the competitiveness of the whole agro-value chain. Examples of approaches could include supporting small agro-producers and small and medium enterprises, enabling market access and developing a supportive institutional environment.

In the context of this paper, agro-industry in the Archipelago refers to small family production units, characterized by the use of artisanal techniques, low technological components, and small-scale production. In this article, agro-industry is considered to be the production of the following product ranges: food products (fruit 
pulp, concentrate, syrup, ice cream, vegetable paste, preserve, jam, honey, sweets, sausage, cold meat, bakery products, and yogurt); chemical-pharmaceutical products (soap, body lotion, detergents, and shampoo); alcoholic beverages; and other products (pollen, tea, cotton cushions and pillows, arts and crafts, jewelry, and cooking oil).

\subsection{The Context of the Archipelago}

The Archipelago of San Andrés, Old Providence, and Santa Catalina forms a province (called a "department" in Colombia, roughly equivalent to a U.S. state) of Colombia. (In the remainder of this paper, the province will be referred to as the Archipelago). The Archipelago is located in the southwestern Caribbean Sea, 700 kilometers off the northern coast of Colombia and 180 kilometers east of the Nicaraguan Atlantic coast (see Figure 1). The Archipelago consists of three major inhabited islands (San Andrés, Old Providence, and Santa Catalina) and numerous islets, cays, and banks, the majority being of coral origin. The terrestrial area is $57 \mathrm{~km}^{2}$. San Andres is the largest island, with $25 \mathrm{~km}^{2}$, Old Providence is $19 \mathrm{~km}^{2}$, and Santa Catalina is $1 \mathrm{~km}^{2}$.

\subsubsection{Demographics}

The population of the Archipelago is composed of three distinct groups: Raizals, descendants of the colonial society made up of African slaves and European colonists, mostly Protestants and Anglophones; immigrants from different departments of Colombia, or continentals, mostly Hispanic and Catholic; and a small foreign community mainly from the Middle East and other islands of the Caribbean, South America, and parts of Europe (Hernandez Thyme, 2010).

In 1953 when San Andres was declared a free port, the island was transformed into a tourist and commercial center, stimulating an intense immigration from the continent and causing a growth rate of 5 percent. Between 1951 and 1973 the population grew unusually quickly, increasing at a rate of 8.3 percent per year. This accelerated the densification of the urban area, which is considered to be one of the most densely populated in the Caribbean (Hernandez Thyme, 2010).

Data from Hernandez Thyme show that in 2005, of a total of 45838 people ( $82.7 \%$ of the census population), more than half $(66.9 \%)$ were at levels of poverty and extreme poverty.

\subsubsection{Employment}

According to the Departamento Administrativo Nacional de Estadística (2009) report, San Andres recorded an unemployment rate of $9.6 \%, 0.7 \%$ more than in 2008 . In that period, the subjective underemployment rate rose $3.4 \%$ and the objective underemployment rate rose by $2.5 \%$. The number of people who consider their income to be inappropriately low for their employment increased in 2009 (Hernandez Thyme, 2010).

\subsubsection{Economy}

Hernandez Thyme argues that currently, the economy of the Archipelago is based primarily on tourism and trade. These activities are complemented by subsistence fishing and agriculture, which are insufficient to supply the islands, making it necessary to import most of the food for daily consumption from mainland Colombia.

Tourism

According to Departamento Administrativo de Planeación (2008), the tourism industry is generating approximately 3.850 direct jobs. The government also seeks to make fuller use of its territory and its marine resources, thinking first and foremost to ensure the food security of the people, but also to offer a greater variety of native products to tourists and to explore the possibility of generating some surplus for export.

Fishery

On the islands, fishing is practiced at an industrial and an artisanal scale, with spiny lobster and queen conch being the most important resources. Their production is almost entirely destined to end up in international markets. Fish production in the area increased significantly in the mid-1980's, with the authorization for foreign vessels belonging to Colombian companies to pursue industrial fishing in the Archipelago; before this time, fishing had been practiced mainly on a small scale (Hernandez Thyme, 2010).

Agriculture

According to Clemente Batalla (1994) and Márquez (1990), since colonization the main productive activity developed was export agriculture. At present, due to competition from the tourism sector, farming has suffered a serious decline in the islands. The activity is limited to crops for family self-sufficiency and community exchange. Based on his studies of the ecosystem of Old Providence and Santa Catalina islands and research about the geographic history of the Archipelago found in Parsons (1964), Márquez (1990) asserts that the islands 
depend on imported food because their agricultural potential is not used properly. Moreover, he suggests that it will be necessary to rearrange agricultural activities to assure a favorable supply of fruits and meat.

Hernandez Thyme (2010) states that one of the factors that affect the agricultural sector is the low availability of water during the summer months (January, February, March, April, and early May). Although the average annual precipitation is 69.17 inches, the construction of sites for rainwater collection is expensive.

Many of the domestic and traditional agricultural production practices that are still used on the island (such as an integrated production model, which integrates agricultural production and raising livestock) are adequate for the environmental conditions, such as type of soil, climate, and humidity, and these activities promote self-consumption as a major source of food security for farming families. Nevertheless, the marginality of agricultural activity on the island is noteworthy. Only $1 \%$ of the island population practices this activity, and its primary function is replaced by products from the foreign market (continental Colombia, the U.S., Panama, and Nicaragua, in particular) which are in strong competition with local products.

Agricultural production is varied. The agricultural products that stand out include: coconut, watermelon, avocado, breadfruit, sugar cane, banana, pineapple, oranges, mango, noni (a tropical fruit), tomato, plantain, papaya, sweet pepper, yucca, yam, and sweet potato. Similarly varied, livestock includes poultry, pigs, goats, and cattle (Hernandez Thyme, 2010).

Increasing the diversity of small-farming livelihood systems through family agro-industry could provide alternative livelihood opportunities for rural people and enhance their capacity for local development. The current government of the Archipelago has identified the necessity to create more effective forms of agricultural production that can serve both as a means to meet local market needs and as a tool to penetrate domestic and Caribbean markets. This could make agriculture a strong cornerstone in the economy of the Archipelago (Departamento Administrativo de Planeación, 2008). Moreover, the government expects to develop medium and long term solutions to the agricultural problems in the Archipelago. This government initiative could be an opportunity for small-scale agro-industries to benefit from the growing interest in agricultural products, and also to become a strong part of the local economy. However, because the Archipelago is a biosphere reserve, agro-industry must be practiced sustainably.

\subsubsection{The Biosphere Reserve}

The Archipelago was declared the Seaflower Biosphere Reserve by UNESCO in the year 2000. The biosphere reserve includes areas of coastal and marine conservation, ecological research areas, areas of protection of surface and groundwater, and areas of environmental education in the Archipelago (Mow, 2005).

According to Mow, the biosphere reserve declaration implies a reconsideration of the current development model in the Archipelago, the forms of land use, and resource utilization. Therefore, it is more than an exercise aimed at international recognition; it is also an internal social recognition of the necessity to refocus development. In addition to what is conventionally done in protected areas (such as research and monitoring), the Seaflower Biosphere Reserve seeks to

1) protect natural resources and the natural environment;

2) promote sustainable development;

3) recover traditional economic activities;

4) diversify the economy through new land use and new employment opportunities;

5) improve educational opportunities;

6) contribute to conflict resolution through co-management; and

7) become a member of the Man And Biosphere Programme and the World Network of Biosphere Reserves (Mow, 2005).

Because "biosphere reserves are based on a longstanding concept that explicitly aims to reconcile conservation and development" (Jaeger, 2005), the pursuit of sustainable economic alternatives should be a priority for the community, government, and other organizations in the Archipelago. With a high percentage of poverty and an increasing unemployment rate in the Archipelago, it becomes necessary to develop ecologically and economically viable production systems to improve the livelihood of the community. Otherwise, the reconciliation of conservation and development will be impossible to achieve. 


\section{Material and Methods}

The intent of this concurrent mixed methods study is to shed light on small-scale agro-industry in the Archipelago in order to determine its sustainability as a livelihood strategy. In the study, surveys of people involved in small-scale agro-industry were conducted. The purpose of using quantitative methods was to generate information about the characteristics of households and individuals who depend on agro-industry as a livelihood strategy. Also, quantitative data were gathered in order to determine the trends in products developed, production processes, technology used, and market and demand for local products.

The qualitative component of the study consisted of interviews with people involved in small-scale agro-industry and with professionals from the local government, NGOs, and academia. The objective of the interviews was to inquire into the perspectives of the study participants concerning the contribution of agro-industry to people's livelihood, different kinds and levels of support available, motivations to participate in this practice, and the potential of agro-industry as a sustainable livelihood strategy. The quantitative and qualitative components were conducted simultaneously in order to test for consistency and complementarity of data and to improve understanding of the results.

\subsection{Data Collection}

Convenience sampling was used to select 30 individuals who are currently processing agricultural and forestry products in the two main islands of the Archipelago: San Andres and Old Providence. The surveys were carried out during the summer of 2010. Participants were identified through several sources. The first source was the database of unidades empresariales (Note 1) available at the Corporacion para el Desarrollo Sostenible del Archipielago de San Andres, Providencia y Santa Catalina (Corporation for the Sustainable Development of the Archipelago of San Andres, Old Providence, and Santa Catalina), called Coralina. The other sources for informants were the United Nations Office on Drugs and Crime (UNODC) and the office of the Secretary of Health. Each respondent was asked to refer others who, to their knowledge, were practicing agro-industry. The criteria for selecting participants were that they lived in a rural area and that they practiced agro-industry on a small scale (e.g., family or individual).

A closed questionnaire survey was used to gather data from the 30 participants. The questionnaire was designed in English and Spanish, given that the participants were from continental and Raizal communities. The data collected in the survey are listed in Table 1.

The interviewer also asked participants about their likelihood to continue practicing agro-industry. In addition, the interviewer looked at the perceptions about the contribution of agro-industry to households' well-being and about the role of institutions and organizations (attitudes towards agro-industry and the role of public and private institutions were measured using a Likert scale).

The majority of the participants were contacted by phone to ask their availability and willingness to participate in the study. Others were contacted directly at their residence. The survey was administered immediately to those who were available, and with others, an appointment was made for a later time. A consent form accompanied the questionnaires, explaining the purpose of the study and the rights of the participants. Before administration of the surveys, respondents were asked if they fully understood the consent form and if they had questions about it. Participants were also instructed that they could ask any question about the content of the survey. After finishing the questionnaire, respondents were asked if they were willing and able to participate in an interview, and their time availability.

During the data collection period, open-ended interviews were also conducted with ten of the entrepreneurs involved in agro-industry, chosen from the questionnaire respondents. Participants were chosen based on their availability. The interviews were held in places where participants were comfortable, such as their residence or place of work. The interview included questions regarding the types of economic activities they performed; their motivation to be involved in those activities; their education and practical experience; their perceptions about the sustainability of agro-industry; the role of different institutions regarding support for the activity; and the challenges and opportunities of agro-industry.

In order to arrange interviews with experts in agro-industry and related areas, professionals from several local institutions were contacted: two participants from the office of the Secretary of Agriculture and Fishery, two participants from Coralina, two participants from the National University, one participant from the Antonia Santos el Rancho high school, one participant from the Servicio Nacional de Aprendizaje (National Service of Apprenticeship), one participant from the office of the Secretary of Health, and one participant from the UNODC. Respondents were asked about their knowledge of current agro-industry production trends; support 
available for people involved in the activity; and their perceptions and opinions regarding current economic, social, and environmental sustainability, challenges and opportunities, and the sustainability potential of agro-industry.

\subsection{Data Analysis}

Following the data collection from 30 surveys and 20 interviews, the data from surveys were tabulated and the interviews were transcribed verbatim (Translations in this article have been provided by the author). Responses from questionnaires were analyzed using descriptive statistics. Emerging themes were identified and analyzed under each research question. The objective was to identify emerging themes within and between interviews, from both experts and entrepreneurs, which related directly to each research question.

\section{Results}

The results section presents the main responses to surveys and interviews. Responses to questionnaires are organized into the following subtopics: characteristics of agro-industry and the households engaged in this practice; different activities which households and individuals are engaged in to ensure diverse sources of income; assets and capabilities which households have access to; contribution of agro-industry to the income and overall wellbeing of the entrepreneurs; and participants' opinions regarding the role of public and private institutions in agro-industry.

The interview responses reflect participants' thoughts on the current role of institutions and organizations in regard to agro-industry and the perceptions about what role they should play, followed by the main ideas expressed regarding the challenges and opportunities agro-industry faces currently within the Archipelago and how they may be addressed, and finally the perceptions about sustainability of agro-industry as a source of livelihood.

\subsection{Survey Responses}

\subsubsection{Characteristics of Agro-industry}

Agro-industry is not the major source of income for the respondents. However, the majority of participants (60\%) have been involved in agro-industry for more than 10 years; this may indicate that it is an activity entrepreneurs enjoy. Although only $40 \%$ of the participants work in agro-industry more than twice a week, $67 \%$ reported that they will very likely continue producing agro-industry products. Based on these figures, one could suggest that agro-industry does not provide an economic income stable enough for participants to work in it full time, even though they enjoy doing it.

The majority of the respondents refer to agro-industry as a business $(90 \%)$, while the remainder produce only for personal consumption. $77 \%$ of the respondents who categorized agro-industry as a business identified themselves as owners. Other roles in the business are volunteers, partners, and employees. Other people involved in the business are friends and family. The majority of their market is located in the Archipelago, but some entrepreneurs sell to the mainland and abroad (36\%). Customers in the Archipelago are residents, tourists, hotels, and restaurants.

The agro-industry products offered are derived from raw materials naturally available in the Archipelago (the list of raw materials is presented in Table 2), which are considered to be exotic and atractive to tourists.

\subsubsection{Demographic Characteristics}

There is a relatively gender-balanced participation in the activity. The participants in the study included male (47\%) and female (53\%) entrepreneurs. Among the male participants, $37 \%$ are head of household. $27 \%$ of female participants are head of household. The greater part of the participants $(83 \%)$ described themselves as Raizals. The majority of participants are married or unmarried-with-partner, and have dependents. Table 3 and Table 4 show the age range of participants in the study and the level of education. As can be seen, agro-industry is most practiced by educated people in their late adulthood.

\subsubsection{Other Activities as Sources of Income}

In the Archipelago, people become involved in agro-industry not as their only source of income but combined with other activities. The most frequently reported sources of other types of income are farming (17\%), job in a private institution $(17 \%)$, job in a public institution $(10 \%)$, and other sources such as self-employment and rental income $(23 \%)$. 


\subsubsection{Assets and Capabilities}

In order to start their agro-industry business, the majority of entrepreneurs used personal savings. Table 5 provides details of the percentage of study participants that used the listed sources of financial resources to invest in agro-industry. Table 6 shows the percentage of participants that have accessed land for agro-industry through the sources listed. As can be seen, overall resources are easily available. However, there is a high non-response rate and it is not possible to determine what these no response answers would have been, which might have skewed the results. To access raw materials, the tendency is to buy. However, some particpants get access to raw materials by growing their own crops, raising their own livestock, fishing independently, or gathering plants that grow wild. From the people who grow their own raw materials, $53 \%$ have access to their own land or family land and only $7 \%$ rent land.

The sample studied showed generally good access to public services. Figure 2 shows the breakdown of the percentage of the study participants that have access to public services. These findings suggest that there is adequate access to these types of assets.

Production processes are carried out mainly in homes. In order to do the processing, entrepreneurs use basic technology. Two out of ten participants have bought equipment such as freezers, pulpers, mills, and cooking pots, specifically for their processing. Other implements bought include specialized chemistry lab equipment, mixers, and measuring instruments. Other participants use cookware and kitchen appliances already available in their homes (such as ovens) and traditional mills (pushed by horses) in their farms. Two participants reported that they have had access to facilities from a university (a chemical lab) and from a technical education institute (a fully equipped kitchen). Because equipment can be easily accessible, starting an agro-industry activity need not be expensive.

$37 \%$ of the participants said they had not received formal training related to agro-industry. Several participants explained that they had been self-taught or had learned the practice from parents. $43 \%$ said they had received training in fields related to agro-industry. Participants reported training in the following areas: business management; utility and sales management; administration of agricltural enterprises; product design; recycling; design of imitation jewerly; processing of herbs; food handling; fruits processing and handling; the HACCP (Hazard Analysis and Critical Control Points) management system; transformation of fishery products; commercialization of fishery products; production of food, medicine, and other products through the cultivation of fungi; agriculture; pig farming; and fish farming.

The majority of the training has been accessed through the National Service of Apprenticeship, which offers free technical courses. Other participants have accessed training in pivate institutions using loans or personal expenses. Other sources of free training include the Chamber of Commerce, the office ot the Secretary of Agriculture and Fishery, and the office of the Secretary of Health. This finding offers evidence that there is availability of technical training programs.

Most of the participants affirmed that they knew about sources of support from either private institutions, public organizations, or both. Word of mouth was the most-reported source of information regarding support for agro-industry or agriculture. The most well-known sources of support are Acción Social (the presidential agency for social action and international cooperation), Coralina (the environmental corporation of the Archipelago), the office of the Secretary of Agriculture and Fishery, the United Nations, the National Service of Apprenticeship, the Banco Agrario (a state-run financial institution that provides banking services for the rural sector, financing agricultural, livestock, forestry, and agro-industry activities), the Ministry of Industry and Commerce, and the Bavaria Foundation (a private non-profit organization whose main objective is to benefit the most needy communities in Colombia through social investment programs aimed at generating employment and income, poverty reduction and progress, and sustainable development of the country). This list suggests that the most available sources of support are from public organizations.

10 out of 30 participants belong to a local group, association, or organization. Nine persons reported benefits received from being affiliated with an organization. The benefits they have received from being part of a group are: access to credit, training, guidance, education in local history and self-determination, technical assistance, support for selling products, access to workshops, and financing of projects. This suggests that practicing associative agro-industry can bring benefits for entrepreneurs.

\subsubsection{Participants' Opinions on the Contribution of Agro-industry and the Role of Institutions and Organizations}

For $77 \%$ of respondents, agro-industry does not provide their main source of income. Among the $23 \%$ that confirmed that agro-industry is their main source of income, $29 \%$ consider that it contributes $40 \%$ to $60 \%$ of 
their income, $29 \%$ that agro-industry contributes $60 \%$ to $80 \%$ of their income, and only $14 \%$ said that agro-industry contributes $80 \%$ to $100 \%$ of their income. The data imply that agro-industry is far from being a main source of income sufficient to encourage someone to work exclusively in it.

When asked about the contribution of agro-industry to their wellbeing, the majority of participants had positive opinions. $47 \%$ of participants agreed that agro-industry is an important source of additional resource for them and their family; $57 \%$ agreed that agro-industry has allowed them to better manage their resources; $40 \%$ agreed that agro-industry has allowed them to better manage their family's resources; $33 \%$ agreed that if they leave this activity it will reduce their income level in a major way; $43 \%$ disagrees that agro-industry generates more loss than profits; and 50\% disagree that it will not affect their quality of life significantly if they leave this activity.

There is a strong agreement on the roles that government should play in providing easily-accessed education and training for farmers and fishermen, while the role of private institutions in providing training and education is not as strongly supported.

\subsection{Interview Responses}

\subsubsection{Role of Institutions and Organizations Regarding Agro-industry}

The interview data revealed that both technical experts and local people involved in agro-industry believe that institutions and organizations play key roles with respect to agro-industry. A fair number of key roles were mentioned: training; technical assistance in growing, transforming, and commercializing; conduct of scientific research and studies; transfer of technology; consultancy regarding production processes; financial assistance; support in development of business plans; monitoring; and motivation.

While the majority of the previous types of support overlapped between the two groups of participants (technical experts and farmers), responses on what the role of institutions and organizations should be differed. On the one hand, according to institutional study participants, organizations and institutions should focus on the following topics: land certification, incentivizing change of habits, compromise, knowledge transfer, political will, facilitation of organizations (associations or other groups with a common goal and that work towards that goal), and creation of clear policies to support local production.

Farmers, on the other hand, think the ideal roles organizations and institutions should play are to: provide publicity, create a space in the market, create a sales showcase or exhibit for small producers, promote marketing, teach promotion topics, create strategies to contact buyers, make contact with organic products buyers, help improve sales, provide access to land to grow crops, help in product improvement, redirect money confiscated from drug trafficking to islanders who want to make a legitimate business, provide strategies to grow crops year round, provide one or two types of machines, limit the number of products brought from the mainland (especially products that are produced on the islands), collaborate with other institutions, design a clear economic vision from the government, act as consumers of local products, and educate members of the government.

Both experts and entrepreneurs reveal a considerable knowledge about available instruments of support to farmers, fishermen, and agro-industry entrepreneurs. Most of the support relates to technical assistance, training, and financial support (loans and grants). Some sources of support are local and some are at the national level.

Although two entrepreneurs said they received support from national private institutions, the technical experts consulted in this study see limited opportunities for islanders to access the majority of opportunities provided at the national level. This is because of the requirements they need to fulfill in order to receive such support. For example, the minimum lot size needed in order for a farmer in the country to access one particular government subsidy exceeds the size of any farm on the Archipelago, due to the small size of the islands. The private institutions that were mentioned are Bavaria and the Mario Santo Domingo Foundation, which are private non-profit organizations that assist social development programs in the country.

Other specific support programs highlighted by the participants were: the Seaflower's Keepers, two programs provided by the Office of the Secretary of Agriculture and Fishery, and a tax exemption government policy. The Seaflower's Keepers is a program initiated by the UNODC, which provides a montly "allowance" for farmers, fishermen, and people who process agricultural products and encourages organization by requiring these people to be affiliated in order to receive benefits. This same office is aranging to buy land from the Dirección Nacional de Estupefacientes (National Narcotics Directorate) and to redistribute these lands to farmers. The Office of the Secretary of Agriculture and Fishery is also implementing a project of planting fruit trees initially to contribute to rural families' nourishment and quality of life and further to allow them to engage in fruit processing. Finally, 
according to an expert from the office of the Secretary of Agriculture and Fishery, there is a $30 \%$ land tax exemption for land owners who engage in agriculture.

According to the participating technical experts, agro-industrial practices in the archipelago are very artisanal and do not require the use of cutting edge technology. This makes it easy and inexpensive to provide equipment to support this practice. One example of an attempt to stimulate production using minimal modern equipment was a project through which the local government, through the office of the Secretary of Agriculture and Fishery, provided industrial stoves with three burners, 100-pound gas cylinders, and small refrigerators to three schools. The stoves, cylinders, and refrigerators were specifically designated to implement a project to teach students and teachers how to produce dairy and meat products. The project was not executed for the projected length of time, due to economic resource constraints. However, though it is not being used, the equipment at the schools is available only for students and teachers at those schools.

Likewise, The National Service of Apprenticeship institute has provided access to fully-equipped kitchens for entrepreneurs who need equipment and space to conduct their processing. This support could be very beneficial for entrepreneurs because it represents free access to resources. However, some experts report that the majority of people who produce food products, who are the single group that would most use the kitchens, are women heads-of-household, who do not have the time to go to the institute to use the equipment. It may be necessary to consider an alternative strategy to bring these resources closer to where these women make their products, perhaps the installation of communal kitchens in neighborhoods where they reside. Another alternative could be to allow those entrepreneurs engaged in agro-industry who live close to the schools where the local government equipment is housed to access these resources.

\subsubsection{Perceived Challenges and Opportunities of Agro-industry}

\section{Challenges}

Participants agree that there are challenges to agro-industry in the Archipelago. There is a common agreement that the lack of local markets, lack of financial resources, and lack of distribution channels constrain sales. Also, challenges specific to the processes include the lack of standard quality products and the lack of technology (especially for packaging). Additionally, some respondents think the lack of raw material due to limited land area creates difficulties for agro-industry development.

Regarding individuals, there was mention of cultural aspects that make local people reluctant to organize for cooperative commercial ventures. Some respondents referred to lack of vision, lack of perseverance, lack of patience, lack of a culture of entrepreneurship, and lack of motivation and interest (according to survey participants, especially among the younger generation). Other types of challenges mentioned were lack of information transfer (from research and studies), lack of internal policy, lack of political will, and inability to meet requirements from INVIMA (Instituto Nacional de Vigilancia de Medicamentos y Alimentos or National Institute of Medicines and Food Monitoring) in order to sell their products.

In order to overcome these challenges, participants think the products offered need to be improved, in the sense that entrepreneurs need to provide consistent quality products and a good presentation. Others think that what is needed is to build local knowledge on how to improve efficiency. Still other participants think that what is needed is collaboration; for example, "everyone needs to be onboard" (local agronomist, personal communication, June 8, 2010).

\section{Opportunities}

The perceived opportunities are based on the demand for local products. Some respondents think that there are market opportunities in tourism. The considerable output of agricultural products not being consumed and the abundance and sometimes waste of exotic fruits are seen as potential opportunities. Although some participants perceive the small land area of the islands as a challenge for providing raw materials in a constant way, if agro-industry is kept at a small scale the abundance of fruits and other agricultural products may actually provide constant raw materials for agro-industry.

Some respondents think that overcoming challenges (for example, achieving packaging and final presentation standards) will create an opportunity to access national and international markets, given that the physical infrastructure for exporting products already exists. "Boats and planes come to the island full and always go away empty", said an expert from an academic institution (local agronomist, personal communication, June 8, 2010).

A significant number of respondents think that there is potential in agro-industry. Moreover, there are many studies done on the topic, but no practical action has resulted from them. As one of the participants stated, "San 
Andrés is one of the most studied territories. What we need is to do, what we need is to act" (local agronomist, personal communication, June 15, 2010).

\subsubsection{Perceptions about Sustainability of Agro-Industry}

This topic received the most division among participants. Almost half of the respondents advocate for the sustainability of agro-industry, but the others think it is not sustainable as it is. The respondents who perceived agro-industry to be sustainable referred to economic and environmental sustainability. Responses that were positive towards sustainability included the promotion of agriculture, employment generation, improvement of soil quality, stimulation of growth of regional flora and fauna, offering of value-added products, abundance of raw materials (fruits especially), naturally organic farming (very little or no use of chemicals, e.g., urea-based fertilizers), and very fertile soil, in which "anything grows" (local marketing expert, personal communication, June 4, 2010).

Although some participants agree that agro-industry is sustainable, they state that in order for it to remain that way, production needs to be at a small scale, focusing on quality rather than quantity, and offering products at high prices. A participant from the office of the Secretary of Agriculture observes: "I think San Andrés has to do agro-industry but of highly elaborated products. Expensive products offered to a specific market where not much raw material is used. Low supply of highly elaborated products with a good merchandising because of a good product offered. That guarantees that the resources are not overexploited. Just the way it is happening now, but with technology, innovation, and family business, and more efficient" (local agronomist, personal communication, June 15, 2010).

Respondents who believe that agro-industry is not sustainable think that the limited land area due to the size of the island cannot ensure availability of raw material to process. Moreover, there is the problem of water storage for irrigation, and the threat of climate change, both of which will place further stresses on the production of crops. The seasonality of production does not enable agro-industry to be a constant activity. An expert from Coralina explains that "agro-industry is based on three links: production, transformation, and commercialization. If the production system is flawed, and the links are consecutive, it is very difficult to have a strong production" (local agro-industrial engineer, personal communication, June 15, 2010).

In order to make agro-industry sustainable, participants' perception is that production needs to be guaranteed. In order to achieve that, according to some respondents, farmers need to unite, money is needed in order to develop an irrigation system, a market needs to be guaranteed, technology is needed, policies that protect local production are needed, commitment by entrepreneurs is needed, and pilot projects need to be developed.

Although there were not many comments addressing the social sustainability of agro-industry, some believe it can become an important support for other economic activities. One respondent, for example, said that when her business is fully operating, she plans to employ local people and buy local ingredients. She said: "When I start my business it will impact fishermen from the cooperative, the person who is growing sweet pepper, and so, they are my first choice to buy my ingredients from. I want to work with islanders" (local agro-industrial entrepreneur, personal communication, June 15, 2010).

According to some respondents, agro-industry currently does not have many social or economic implications for the community. Nevertheless, some experts believe agro-industry has a high potential to positively impact in the future by providing another source of income and employment. A participant stated, for example, that a "farm gives money. If you get money out of a cow, take a sub-product out of it, it will give you more money" (local agronomist, personal communication, June 8,2010 ). However, it is necessary to educate children and motivate the younger generations to get involved in the sector.

At the household level, agro-industry has not had a considerable economic impact, but at a personal level, it has motivated people to study and enhance their knowledge. A participant entrepreneur stated: "It has made me grow as a person" (local agro-industrial entrepreneur, personal communication, June 15, 2010).

\subsubsection{Reasons for Engaging in Agro-industry}

Entrepreneurs did not get involved in agro-industry seeking to profit from it (only 1 out of 10 mentioned seeking a source of income as a motivation to get involved in agro-industry). Rather, they report an interest in learning. Some were motivated to engage in it by other people (e.g., family), while others saw a high availability of raw materials (e.g., a variety of tropical fruits) as an opportunity to produce new things. Although the majority do not work primarily in agro-industry and the principal driver to get involved was not economic, they did mention that if they had a stable market that would allow them constant sales, they would engage in it full time. 


\section{Discussion}

Research has shown that rural households tend to diversify their sources of livelihood (activities, assets, and capabilities) in order to ensure survival (e.g., see Ellis, 1998; Koczberski \& Curry, 2005; Niehof, 2004; Tao \& Wall, 2009). Furthermore, as discussed in Section 1.1, a livelihood will be sustainable if it can deal with stresses and shocks, it has positive impacts now and in the future, and it does not undermine the natural resource base (e.g., see Bhandari \& Grant, 2007; Brocklesby \& Fisher, 2003; Chambers \& Conway, 1992; de Haan \& Zoomers, 2005; Kaushal \& Kala, 2004; Scoones, 1998; Tao \& Wall, 2009). The purpose of this study was to determine to what extent agro-industry is a sustainable livelihood strategy for rural households in the Archipelago. In order to evaluate the present sustainability of agro-industry, it was necessary for the researchers to understand how the activities, assets, and capabilities are currently used.

There is consensus in the literature that rural households diversify their sources of income (Ellis, 1998; Koczberski \& Curry, 2005; Niehof, 2004; Tao \& Wall, 2009). The results of this study indicate that rural households' livelihood activities are composed of farming, self-employment, agro-industry, fishery, and jobs with private and public organizations. Small-scale agro-industry is seen as a complementary activity performed mostly by educated Raizal adults in their fifties. Raizals have a history of development of fishery and agriculture, which may account for their willingness to expand into agro-industry more readily than other population groups. Also, given that in this study the participation of male and female entrepreneurs is nearly balanced, it is suggested that women have integrated into the economic activity in the community and benefit equally from the outcomes. The low motivation of younger generations to participate in this activity could be a result of the low percentage of income from agro-industry and the economic instability of this activity.

Training and education are given a high importance by the participants. Capabilities and human capital have been built through personal initiative. Being involved in agro-industry has motivated people to build on their knowledge and skills. Social capital, such as affiliation with cooperatives, seems not to be the norm among participants. In order to incentivize entrepreneurs to associate an economic reward may be necessary. It would be important for entrepreneurs to create cooperatives or other forms of associations that will help build on the strengths of each and overcome the weaknesses. Also, it might help them to meet the specific requirements of support programs.

Agro-industry is based mainly on the processing of local products and on artisanal processes that do not necessarily depend on advanced technology. This has made access to equipment and raw materials easy. Assets such as land, economic resources, equipment, skill upgrading, and public services have also been easily accessible. However, there has been very limited access to markets, which has constrained receiving high and steady economic income from agro-industry.

Researchers support the inclusion of market elements when developing policies to address rural development and sustainable livelihood (Barrett et al., 2001; Gandhi et al., 1999; Punjabi, 2007; Smilga-Palardy, 2006). Oyewole and Phillip (2006) propose that in order to overcome challenges such as quality assurance, improved production and processing capacity, and overcoming market limitations, farmers need to organize and need to have access to training in quality assurance and marketing.

Institutions and organizations play key roles in establishing a platform for agro-industry. Some private organizations have focused on providing financial resources, while public organizations have been focused on education. Experts from public organizations are aware of the needs and challenges faced by local entrepreneurs (e.g., guaranteeing water for irrigation and accessing markets). However, up to now, expert support has been focused specifically on the transformation process, and not on the marketing and commercialization stages.

A livelihood system needs to be viewed in a holistic way, in which all of its components are addressed. In the case of agro-industry in the Archipelago, training and technical assistance for developing brand recognition, creating high quality standardized products, and developing marketing strategies are lacking. When designing support mechanisms for agro-industry, organizations need to create more strategies to access the market and guarantee constant income from this activity.

As mentioned earlier, in order to be sustainable a livelihood system needs to be able to deal with stresses and shocks. The evidence suggests that agro-industry is not sustainable. Due to the fact that the supply of agricultural raw materials is seasonal, the ability of entrepreneurs to deal with shocks and stresses may be undermined. Agro-industry may also be negatively affected by economic shocks, in the sense that a recession could decrease demand for the products offered. Given that the younger generation is not strongly involved in agro-industry and that to them the economic benefits derived from it are not perceived to be of high relevance, the future successful practice of agro-industry does not seem to be a high possibility. 
On the other hand, agro-industry has the potential to become sustainable. There is an abundance of native fruits, and the small scale of agro-industry practices infer that the resources are not currently being over-exploited. Although there is no irrigation infrastructure on the islands, it appears that farmers have adapted to the rain seasons in order to grow crops. Overall, traditional agricultural practices seem not to have a negative impact on the soil. Given that the trend in agro-industry is to process local products, there is potential to have a positive impact on other livelihoods (e.g., farming and fishing), due to the demand of local agricultural products as input for agro-industry. However, for agro-industry to become a sustainable practice it will be necessary to ensure that raw materials are provided on an ongoing basis while practices remain at a small scale.

People are involved in agro-industry for personal motivations rather than economic ones. Nevertheless, they express the desire to participate fully in this activity if an economic incentive is present. There is high awareness of the challenges of agro-industry and a desire to overcome them. Availability of water for irrigation appears to be the major constraint for guaranteeing a constant production, and limited access to markets seems to be the major constraint for receiving economic benefits from agro-industry. Solving these problems could have a boosting effect on agro-industry's sustainability.

\section{Conclusions}

This paper has reviewed agro-industry-based rural livelihoods in a Colombian Archipelago using the sustainable livelihood approach. A combination of qualitative and quantitative research methods was used to characterize agro-industry and illustrate people's perceptions about this activity. The literature suggests that rural livelihood diversification into several activities increases households' ability to cope with risks and face shocks. Given the high dependence of agro-industry on agricultural outputs, agro-industry in the Archipelago faces the same vulnerability as any agricultural practices. Consequently, agriculture needs to be strengthened in order to make agro-industry sustainable.

Analysis of survey and interview responses indicates that people are highly motivated to be involved in agro-industry, even though it does not account for the majority of their income. Participants have a positive opinion regarding the contribution of agro-industry to their wellbeing. If entrepreneurs create networks and associations, they may receive not only social but also economic benefits.

Extensive research results also indicate that engaging in nonfarm activities, including those of agro-industry, can improve rural livelihoods. In order to serve as a means out of poverty, agro-industry must provide higher and constant economic returns for rural households. Although it was revealed in this study that agro-industry faces challenges that constrain its sustainability, people perceive that agro-industry has the potential to become a sustainable source of livelihood. However, the long-term viability of this activity is doubtful unless the sector is strengthened. In this vein, institutions and organizations play crucial roles. Institutions and organizations may enable a vibrant economic sector by prioritizing support strategies based on the understanding of the particularities of the Archipelago, such as the small size of the islands and the unique demographic and socio-economic factors. Interventions should be focused on creating networks of collaboration and policies to support local production (e.g., ensuring provision of water for irrigation and protecting local production) and securing access to markets (e.g., developing links with potential customers and creating physical infrastructure for promotion).

Finally, the biosphere reserve declaration calls for implementation of programs that support traditional economic activities and provide opportunities for sustainable development. This study has shown that agro-industry in the Archipelago is based on practices that are not currently undermining the resources; it has the potential to be a sustainable activity; it involves the use of traditional practices and local products; it is a way of diversifying the economy and creating employment; and it has contributed to educational development. These factors contribute to five out of the seven objectives of the biosphere reserve (objectives 1,2, 3, 4, and 5 as presented in Section 1.3.4). Strengthening agro-industry-based livelihoods would be a favorable strategy for achieving the objectives of the biosphere reserve.

According to the 2005 census, 70554 people inhabit the Archipelago, and of these, only 1\% practice agricultural activities (Hernandez Thyme, 2010). A database of the entire population that practices agro-industry in the Archipelago could not be found. For this reason, the determination of a suitable representative sample size was difficult. However, despite the small study sample, this research provides an insight into the current situation of the agro-industry sector in the Archipelago. Future population studies could improve this understanding.

Given the importance of nonfarm diversification for improving rural livelihoods, further studies that examine how people address shocks and stresses could be helpful for the design of interventions to enhance people's current coping and adaptive strategies. Further analysis that details how modern technology could complement 
local knowledge to attain standardized high quality products could be productive. Also, assessment of the reasons for low participation of certain age groups could serve as a base for creating incentives for involvement in agro-industry.

\section{Acknowledgments}

The authors would like to thank Professor Maria Hosmer-Briggs for her help and her direction with this project.

\section{References}

Barrett, C. B., Reardon, T., \& Webb, P. (2001). Nonfarm income diversification and household livelihood strategies in rural Africa: Concepts, dynamics, and policy implications. Food Policy, 26 (4), 315-331. http://dx.doi.org/10.1016/S0306-9192(01)00014-8

Bhandari, B. S., \& Grant, M. (2007). Analysis of livelihood security: A case study in the Kali-Khola watershed of Nepal. Journal of Environmental Management, 85 (1), 17-26. http://dx.doi.org/10.1016/j.jenvman.2006.07.010

Boucher, F., \& Riveros, H. (2000). La agroindustria rural de América Latina y el Caribe, tomo 1, su entorno, marco conceptual e impacto. San José, Costa Rica: Instituto Interamericano de Cooperación para la Agricultura.

Brocklesby, M. A., \& Fisher, E. (2003). Community development in sustainable livelihoods approaches: An introduction. Community Development Journal, 38 (3), 185-198. http://dx.doi.org/10.1093/cdj/38.3.185

Chambers, R., \& Conway, G. R. (1992). Sustainable rural livelihoods: Practical concepts for the 21st century. Brighton: Institute for Development Studies at the University of Sussex, Discussion Paper 296.

Clemente Batalla, I. (1994). El Caribe insular: San Andrés y Providencia. In A. Meisner Roca (Ed.), Historia económica y social del Caribe colombiano. Bogotá: Ediciones Uninorte.

De Haan, L., \& Zoomers, A. (2005). Exploring the frontier of livelihoods research. Development and Change, 36 (1), 27-47. http://dx.doi.org/10.1111/j.0012-155X.2005.00401.x

Departamento Administrativo de Planeación. (2008). Living islands for all. Por un desarrollo social, sostenible, con valores y participación equitativa de los habitantes del archipiélago. 2008-2011. San Andrés Island: Gobernación del Departamento Archipiélago de San Andrés, Providencia y Santa Catalina.

Departamento Administrativo Nacional de Estadística. (2009). Informe de coyuntura económica regional. Archipiélago de San Andrés, Providencia y Santa Catalina. San Andrés Island.

Ellis, F. (1998). Household strategies and rural livelihood diversification. Journal of Development Studies, 35 (1), 1-38. http://dx.doi.org/10.1080/00220389808422553

Ellis, F., \& Bahiigwa, G. (2003). Livelihoods and rural poverty reduction in Uganda. World Development, 31 (6), 997-1013. http://dx.doi.org/10.1016/S0305-750X(03)00043-3

Ellis, F., \& Mdoe, N. (2003). Livelihoods and rural poverty reduction in Tanzania. World Development, 31 (8), 1367-1384. http://dx.doi.org/10.1016/S0305-750X(03)00100-1

Gandhi, V., Kumar, G., \& Marsh, R. (1999). Agroindustry for rural and small farmer development: Issues and lessons from India. International Food and Agribusiness Management Review, 2 (3), 331-344. http://dx.doi.org/10.1016/S1096-7508(01)00036-2

Gibb, N., \& Smilga-Palardy, G. (2006). Commercialization and artisanal agroindustry: Sustainable livelihood strategies for rural Capira, Panama. McGill University and Conservation through Research, Education and Action Panama. [Online] Available: https://secureweb.mcgill.ca/pfss/sites/mcgill.ca.pfss/files/Natalie_Gibb_Gabrielle_Smilga_Palardy_Report.pdf

Hernandez Thyme, D. (2010). Informe ambiental. Estado actual de los recursos naturales del archipiélago de san Andrés, Providencia y Santa Catalina. San Andrés Island: Contraloría Departamental de San Andrés, Providencia y Santa Catalina.

Hussein, K. (2002). Livelihoods approaches compared: A multi-agency review of current practice. Department for International Development.

Jaeger, T. (2005). New prospects for the MAB programme and biosphere reserves. lessons learned from Latin America and the Caribbean. UNESCO South-South Co-Operation Programme Working Papers $\mathrm{N}^{\circ} 35$. Montevideo: United Nations Educational, Scientific and Cultural Organization (UNESCO).

Kaushal, K. K., \& Kala, J. C. (2004). Applying the sustainable livelihood approach to joint forest management projects in India. International Forestry Review, 6 (1), 13-18. http://dx.doi.org/10.1505/ifor.6.1.13.32059 
Kay, C. (2006). Rural poverty and development strategies in Latin America. Journal of Agrarian Change, 6 (4), 455-508. http://dx.doi.org/10.1111/j.1471-0366.2006.00132.x

Koczberski, G., \& Curry, G. N. (2005). Making a living: Land pressures and changing livelihood strategies among oil palm settlers in Papua New Guinea. Agricultural Systems, 85 (3 SPEC. ISS.), 324-339. doi:10.1016/j.agsy.2005.06.014.

Krantz, L. (2001). The sustainable livelihood approach to poverty reduction: An introduction. Swedish International Development Cooperation Agency.

Márquez, G. (1990). Visión de las islas colombianas. In A. Guarnizo (Ed.), Colombia Caribe. Bogotá, Colombia: Fondo FEN Colombia.

Mow, J. M. (2005). La reserva de biosfera Seaflower: Una opción viable para las islas de San Andrés, Old Providence y Santa Catalina. Anaconda, 6, 22.

Niehof, A. (2004). The significance of diversification for rural livelihood systems. Food Policy, 29 (4 SPEC.ISS.), 321-338. doi:10.1016/j.foodpol.2004.07.009.

Oyewole, O. B., \& Phillip, B. (2006). Agro-food chains and sustainable livelihood. A case study of cassava marketing in Nigeria. Agro-Food Chains and Networks for Development, 107.

Parsons, J. (1964). San Andrés y Providencia: una geografia histórica de las islas colombianas del mar Caribe. Bogotá, Colombia: E. C. Nal.

Punjabi, M. (2007). Emerging environment for agribusiness and agro-industry development in India: Key issues in the way forward. New Delhi: Food and Agricultural Organization of the United Nations.

Scoones, I. (1998). Sustainable rural livelihoods: A framework for analysis. Brighton: Institute for Development Studies at the University of Sussex, Working Paper 72.

Simtowe, F. P. (2010). Livelihoods diversification and gender in Malawi. African Journal of Agricultural Research, 5 (3), 204-216.

Tao, T. C. H., \& Wall, G. (2009). A livelihood approach to sustainability. Asia Pacific Journal of Tourism Research, 14 (2), 137-152. http://dx.doi.org/10.1080/10941660902847187

UN Commission on Sustainable Development. (2008, May). The importance of agro-industry for socio-economic development and poverty reduction. Paper presented for the side event on How Agro-Industry can Help Eradicate Poverty, New York at the UN Commission on Sustainable Development $16^{\text {th }}$ Session.

\section{Notes}

Note 1. Unidades empresariales are micro, small, and medium-sized enterprises, legally constituted. Coralina provides support to these groups to improve development through the implementation of sound environmental practices in the Archipelago. 
Table 1. Survey Items

Knowledge of support for agro-industry

Periodicity of dedication to agro-industry

Household assets

Products offered

Access to public services

Group affiliation and benefits

Household composition and demographic characteristics
Time of experience in agro-industry

Purpose of agro-industry for the household

Markets for goods produced

Infrastructure for production processes

Social capital

Level of training and education

Percentage of household income from agro-industry

Table 2. Raw materials processed for Agro-industry

\begin{tabular}{cccc}
\hline Fruits & Tubers and & Animal & Other Raw Material \\
& Vegetables & Species & \\
\hline Noni & Cucumber & Fish & Aromatic herbs \\
Guava & Sweet potato & Shellfish & Medicinal herbs \\
Plumbs & Sweet corn & Black crab & Coconut shell \\
Grape nut & Yucca & Chicken & Conch shell \\
Coconut & Plantain & Pork & Copra \\
Sugar cane & Yam & Beef & Honey \\
Water melon & & & Ceiba \\
Grocella & & & Babood \\
Tamarind & & & Cotton \\
Oranges & & Wood \\
Sour sop & & Seeds \\
Papaya & & Bamboo \\
Breadfruit & & Wild pine \\
Mango & & Palm \\
& & Cassia fistula \\
& & Nuts \\
& & Sugarcane trash \\
& & Flowers \\
\hline
\end{tabular}

Source: Data from interview and survey responses. 
Table 3. Age range of participant's ranked by number of participants in each range

\begin{tabular}{lcc}
\hline Age Range & $\begin{array}{c}\text { Number of } \\
\text { Participants }\end{array}$ & Percentage \\
\hline $50-60$ & 12 & 40.0 \\
$40-50$ & 6 & 20.0 \\
$60-70$ & 4 & 13.3 \\
$30-40$ & 3 & 10.0 \\
Over 70 & 3 & 10.0 \\
$20-30$ & 2 & 6.7 \\
Total Respondents & 30 & 100 \\
\hline
\end{tabular}

Table 4. Education level

\begin{tabular}{lcc}
\hline Education Level & Percentage & $\begin{array}{c}\text { Number of } \\
\text { Participants }\end{array}$ \\
\hline College & 43.3 & 13 \\
High School & 20.0 & 6 \\
Elementary & 16.7 & 5 \\
Graduate & 6.7 & 2 \\
Some Courses & 6.7 & 2 \\
Technology & 6.7 & 2 \\
Total Respondents & 100 & 30 \\
\hline
\end{tabular}

Table 5. Access to financial resources

\begin{tabular}{lcc}
\hline Source of Resource & $\begin{array}{c}\text { Number of } \\
\text { Participants }\end{array}$ & Percentage \\
\hline Savings & 14 & 46.7 \\
Family investment & 2 & 6.7 \\
Foundation grant & 2 & 6.7 \\
Family investment and family loan & 1 & 3.3 \\
Government grand & 1 & 3.3 \\
Inheritance & 1 & 3.3 \\
Loan from a friend & 1 & 3.3 \\
International cooperation funding & 1 & 3.3 \\
Peddling & 1 & 3.3 \\
Partnerships & 1 & 3.3 \\
No response & 5 & 16.7 \\
Total Respondents & 30 & 100 \\
\hline
\end{tabular}


Table 6. Access to land

\begin{tabular}{ccc}
\hline Source of access & $\begin{array}{c}\text { Number of } \\
\text { Participants }\end{array}$ & Percentage \\
\hline Family & 10 & 33.3 \\
Own & 6 & 20.0 \\
Landowner $^{\text {a }}$ & 4 & 13.3 \\
Rent $^{\text {Shared }}$ & 2 & 6.7 \\
Wild $^{\mathrm{b}}$ & 1 & 3.3 \\
No Response & 1 & 3.3 \\
Total Respondents & 6 & 20.0
\end{tabular}

Note: ${ }^{a}$ By verbal consent from the land owner. ${ }^{b}$ 'Wild' refers to harvesting from growing sites that are not conventionally maintained.

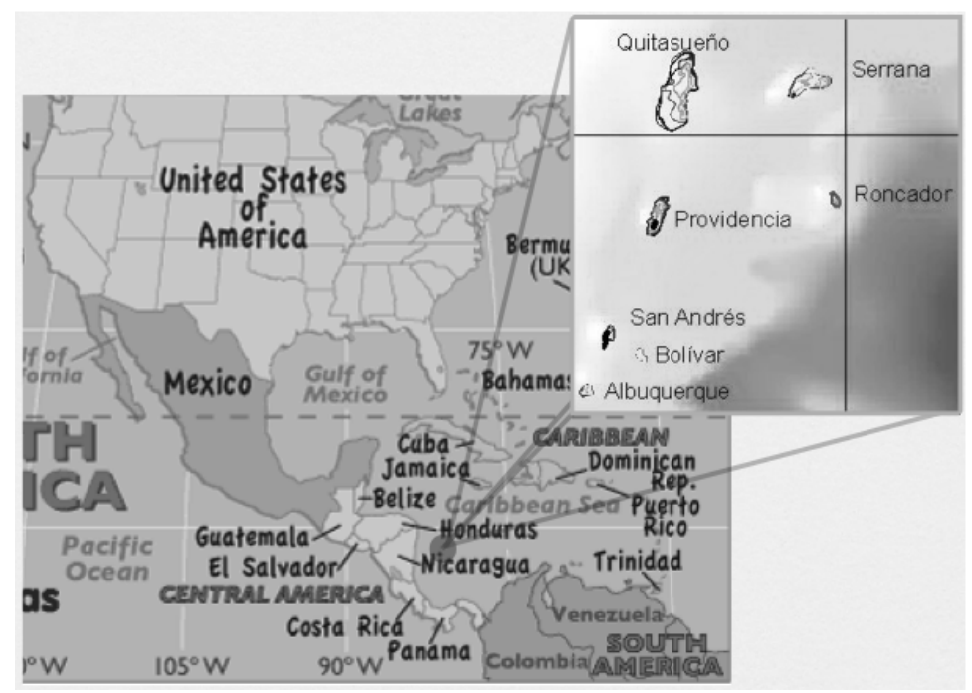

Figure1. Geographic location of the archipelago 


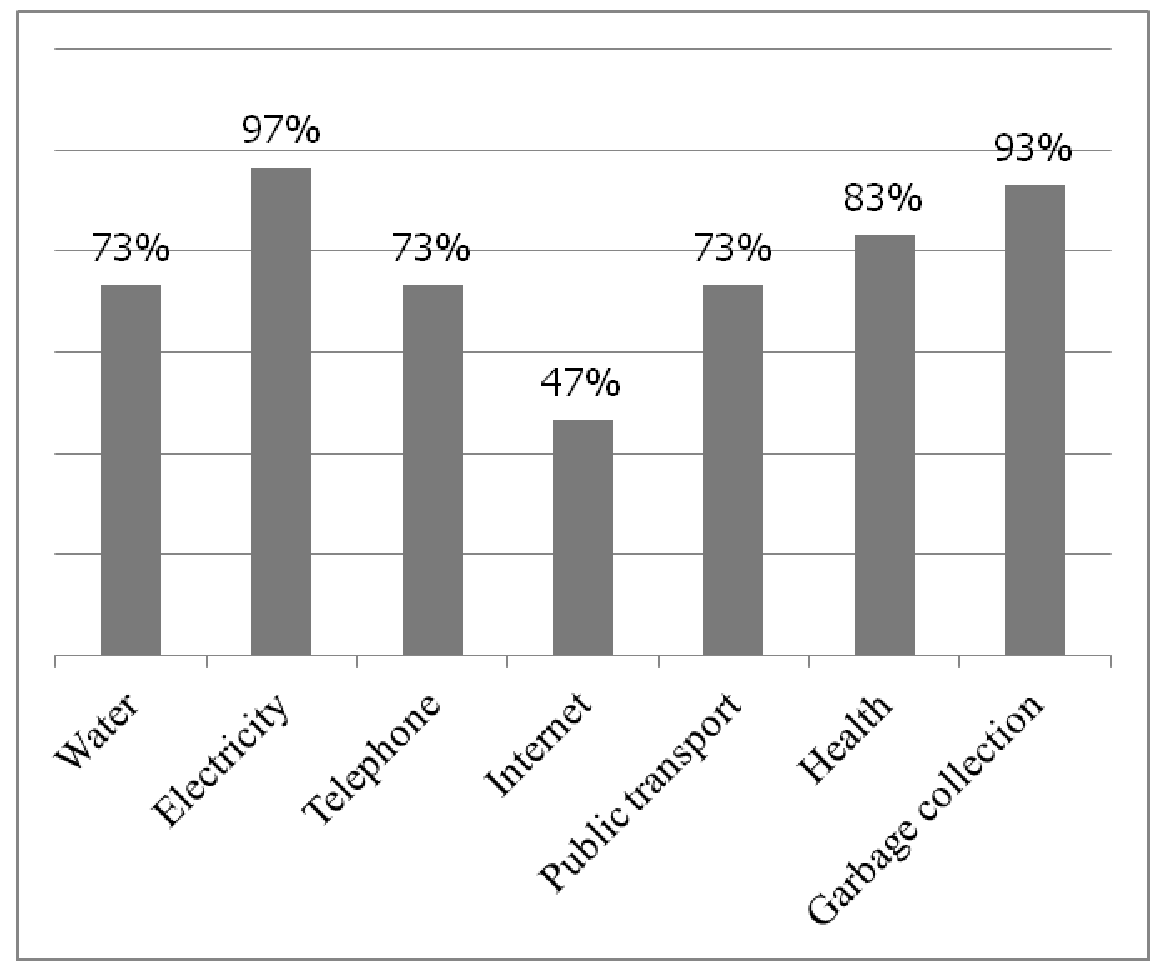

Figure 2. Access to Public Services, showing the percent of the study population that has access to each service 